\title{
Dopaminergic Signaling Mediates the Motivational Response Underlying the Opponent Process to Chronic but Not Acute Nicotine
}

\author{
Taryn E Grieder*,', Laurie H Sellings ${ }^{2}$, Hector Vargas-Perez ${ }^{2}$, Ryan Ting-A-Kee', Eric C Siu ${ }^{3}$, \\ Rachel F Tyndale ${ }^{3}$ and Derek van der Kooy ${ }^{1,2}$ \\ IInstitute of Medical Science, University of Toronto, Toronto, ON, Canada; ${ }^{2}$ Department of Medical Genetics and Microbiology, University of \\ Toronto, Toronto, ON, Canada; ${ }^{3}$ Center for Addiction and Mental Health and Department of Pharmacology, University of Toronto, Toronto, ON, \\ Canada
}

\begin{abstract}
The mesolimbic dopamine (DA) system is implicated in the processing of the positive reinforcing effect of all drugs of abuse, including nicotine. It has been suggested that the dopaminergic system is also involved in the aversive motivational response to drug withdrawal, particularly for opiates, however, the role for dopaminergic signaling in the processing of the negative motivational properties of nicotine withdrawal is largely unknown. We hypothesized that signaling at dopaminergic receptors mediates chronic nicotine withdrawal aversions and that dopaminergic signaling would differentially mediate acute vs dependent nicotine motivation. We report that nicotine-dependent rats and mice showed conditioned place aversions to an environment paired with abstinence from chronic nicotine that were blocked by the DA receptor antagonist $\alpha$-flupenthixol ( $\alpha$-flu) and in DA D 2 receptor knockout mice. Conversely, $\alpha$-flu pretreatment had no effect on preferences for an environment paired with abstinence from acute nicotine. Taken together, these results suggest that dopaminergic signaling is necessary for the opponent motivational response to nicotine in dependent, but not non-dependent, rodents. Further, signaling at the DA $D_{2}$ receptor is critical in mediating withdrawal aversions in nicotine-dependent animals. We suggest that the alleviation of nicotine withdrawal primarily may be driving nicotine motivation in dependent animals.
\end{abstract}

Neuropsychopharmacology (2010) 35, 943-954; doi: I 0.1038/npp.2009.198; published online 23 December 2009

Keywords: conditioned place preference; aversion; dopamine; withdrawal; motivation; $\mathrm{D}_{2}$ receptor

\section{INTRODUCTION}

Nicotine is the major reinforcing constituent of tobacco smoke that is responsible for smoking dependence in humans (Stolerman and Jarvis, 1995). Nicotine causes its motivational effects by acting on nicotinic receptors localized in the mesocorticolimbic dopamine (DA) system (Koob and Le Moal, 2001; Mansvelder and McGehee, 2001). Like most drugs of abuse, nicotine increases the extracellular concentration of DA in the mesolimbic system (Di Chiara and Bassareo, 2007; Picciotto and Corrigall, 2002). Nicotine also produces motivational effects through non-dopaminergic neural systems, such as the cholinergic tegmental pedunculopontine (TPP) nucleus (Lanca et al, 2000; Laviolette et al, 2002; Picciotto and Corrigall, 2002). The mesolimbic DA system has been implicated

\footnotetext{
*Correspondence: TE Grieder, Institute of Medical Science, University of Toronto, I I I 0- 160 College Street, Toronto, Ontario, Canada M5S 3EI, Tel: + 416978 4539, Fax: + 416978 2666,

E-mail: taryn.grieder@utoronto.ca

Received 26 June 2009; revised 2 November 2009; accepted 2 November 2009
}

in the processing of the acute motivational properties of nicotine (Laviolette and van der Kooy, 2003; Laviolette et al, 2008; Spina et al, 2006; Tanabe et al, 2008); however, the involvement of dopaminergic signaling in the aversive response to chronic nicotine withdrawal is largely unknown.

The most common reason for relapse reported by quitting smokers is the desire to relieve the discomforts of withdrawal (Allen et al, 2008). The aversive abstinence syndrome experienced by quitters as well as the ability of renewed nicotine use to relieve this syndrome likely contributes to relapse. Similar to nicotine withdrawn humans, rodents that undergo spontaneous withdrawal show a somatic nicotine abstinence syndrome (EppingJordan et al, 1998; Malin et al, 1992; Stoker et al, 2008). The negative affective state of withdrawal and its alleviation by nicotine is one of the primary factors driving nicotine craving in nicotine-dependent subjects. A majority of the studies on nicotine motivation in dependent animals involve antagonist precipitated withdrawal (George et al, 2007; Kenny and Markou, 2001; Laviolette et al, 2008; Watkins et al, 2000). However, a spontaneous withdrawal procedure more closely models human withdrawal. 
When a psychoactive drug triggers a motivational response, animals will experience a rebound motivational state (Koob et al, 1989; Koob and Le Moal, 2001; Robinson and Berridge, 2003; Wise, 1996) that is predicted by the opponent process theory of motivation (Solomon and Corbit, 1974). This theory postulates that any motivational stimulus activates two opposing motivational processes: the a-process has a fast onset and offset and the b-process is opposite in direction, lasts longer and is slower to start and end (Figure 1a). Similar to other drugs of abuse, chronic nicotine produces a negative withdrawal syndrome that can be viewed as the opponent process to the rewarding effects of nicotine in dependent subjects (Gutkin et al, 2006; Koob and Le Moal, 1997). Acute nicotine produces both rewarding and aversive stimulus properties (Laviolette and van der Kooy, 2004; Sellings et al, 2008; Wilkinson and Bevins, 2008). Dopaminergic signaling is involved in acute nicotine aversion (Laviolette and van der Kooy, 2003; Tan et al, 2009) and chronic nicotine motivation (Bruijnzeel and Markou, 2005; Kenny and Markou, 2001; Laviolette et al,

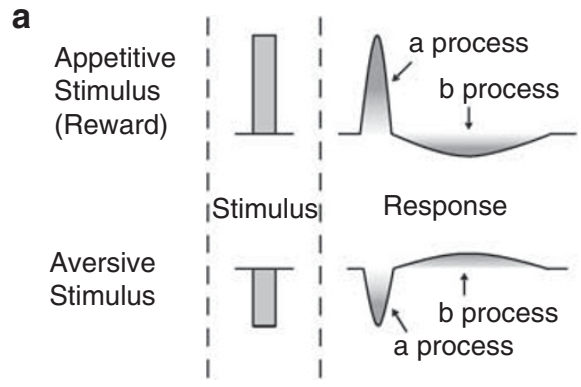

\section{b}

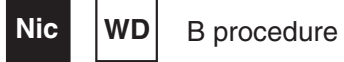

Nic N procedure

WD W procedure

Figure I (a) The opponent process theory of motivation. Solomon and Corbit (1974) postulated that any stimulus would trigger an initial aprocess that will closely follow the stimulus and will be fast to occur and fast to end. The a-process can be rewarding or aversive and will be followed by a later occurring b-process that is longer lasting, slower to end and is opposite in direction to the a-process. At the dose used in the present experiments, acute nicotine is aversive and the a-process is therefore negative. The acute nicotine b-process will be later occurring and positive or rewarding. We postulate that chronic nicotine elicits a rewarding a-process in dependent animals and the aversion to nicotine withdrawal is the conditioned opponent b-process. (b) The $\mathrm{B}, \mathrm{N}$, and $\mathrm{W}$ procedures. In procedure $B$, each animal experienced the effects of nicotine in one environment (Nic) and the lack of nicotine (or the effects of withdrawal) in the other environment (WD). Procedure B measures both the rewarding value of the drug itself and the aversiveness associated with drug withdrawal. In procedure N, each animal was conditioned only while experiencing the effects of chronic nicotine. On the alternate day, the animals experienced withdrawal in their home cage. Procedure $\mathrm{N}$ measures the rewarding value of the drug itself. In procedure $W$, conditioning took place only while the animals experienced withdrawal from nicotine. On the alternate day, the animal was confined to its home cage during chronic nicotine exposure. Procedure $\mathrm{W}$ measures only the aversive motivational effects of drug withdrawal, separate from the rewarding value of the drug itself.
2008; Smolka et al, 2004); however, little is known regarding the role of dopaminergic signaling in the opponent motivational processes of acute and chronic nicotine.

We thus analyzed the role of dopaminergic signaling in the acute and chronic nicotine $\mathrm{a}$ - and $\mathrm{b}$-processes. We first studied the correlation between somatic and affective nicotine withdrawal by examining the timing of the maximal somatic withdrawal syndrome and motivational withdrawal in a place conditioning paradigm. Next, we subjected previously drug naive and nicotine-dependent rodents to place conditioning after acute and chronic nicotine, respectively, and examined the opponent motivational processes after nicotine exposure. The involvement of dopaminergic signaling in the aversive a-process and rewarding $b$-process of acute nicotine and the rewarding a-process and aversive b-process of chronic nicotine was analyzed by treatment with the DA receptor antagonist $\alpha$-flupenthixol $(\alpha$-flu) before conditioning. We also examined $\mathrm{D}_{2}$ receptor involvement in chronic nicotine withdrawal aversions. The $\mathrm{DA} \mathrm{D}_{2}$ receptor has been implicated in nicotine dependence (Fehr et al, 2008) and withdrawal (Laviolette et al, 2008). Our results show that acute aversive and chronic rewarding nicotine lead to opponent a- and bprocesses and that dopaminergic signaling, specifically at the $\mathrm{D}_{2}$ receptor, mediates the opponent motivational process of chronic aversive but not acute rewarding nicotine.

\section{MATERIALS AND METHODS}

\section{Animals}

Male wild-type mice were C57BL/6 $(n=329$; Charles River, Montreal, Canada) weighing 25-35 g. Heterozygous fifthgeneration $\mathrm{D}_{2}$ breeder mice were received as a gift (Kelly et al, 1997) and crosses were bred at the University of Toronto to obtain homozygous male $\mathrm{D}_{2}$ receptor knockout (KO) mice $(n=26)$ and their controls $(n=20)$. Mice were housed individually in plastic cages in a sound-attenuated room at a temperature of $22{ }^{\circ} \mathrm{C}$ with lights on from 0700 to 1900 hours. Male Wistar rats (Charles River) weighing 330$380 \mathrm{~g}(n=128)$ were individually housed in Plexiglas cages in a room kept at a temperature of $22^{\circ} \mathrm{C}$ with lights on from 0700 to 1900 hours. All animals had ad libitum access to food and water except during behavioral testing. All procedures were approved by the University of Toronto Animal Care Committee in accordance with the Canadian Council on Animal Care guidelines.

\section{Chronic Nicotine Treatment}

(-)-Nicotine hydrogen tartrate salt (Sigma-Aldrich, Ontario) titrated to a $\mathrm{pH}$ of $7.0 \pm 0.3$ or saline was administered to mice $(n=263)$ and rats $(n=128)$ using osmotic minipumps (models 1002 and 2001, respectively; Alzet, Cupertino, CA). Animals were anesthetized by inhalation of 5\% isofluorane in oxygen (1-2\% maintenance) and the minipump placed subcutaneously between the scapulae parallel to the spine. Nicotine was administered at doses of 1.4 and $7 \mathrm{mg} / \mathrm{kg} /$ day (free base) for 13 days in mice and 1 and $3.15 \mathrm{mg} / \mathrm{kg} /$ day (free base) for 7 days in rats based on previous studies showing that these doses induce nicotine dependence with 
the expression of spontaneous somatic withdrawal signs (Damaj et al, 2003; Malin et al, 1992, 2006; Watkins et al, 2000). After minipump implantation, the surgical wound was sutured and treated with Polysporin antibiotic cream. Due to the faster metabolism of mice in comparison with rats (Matta et al, 2007), mice were exposed to chronic nicotine for 6 additional days.

\section{Blood Analysis}

Blood was collected by cardiac perfusion from nicotinedependent mice $(n=3)$ after 12 days of exposure at the $7 \mathrm{mg} / \mathrm{kg} /$ day dose. Samples were then analyzed by highperformance liquid chromatography as described previously (Siu and Tyndale, 2007).

\section{Somatic Withdrawal Assessment}

Wild-type mice $(n=24)$ were observed for somatic signs of nicotine withdrawal at $30 \mathrm{~min}, 4,8,12,24$, and $48 \mathrm{~h}$ after minipump removal. A group of $\mathrm{DA} \mathrm{D}_{2} \mathrm{KO}$ mice $(n=6)$ were also observed for somatic signs of withdrawal at $8 \mathrm{~h}$ after minipump removal. Rats $(n=24)$ were observed at $30 \mathrm{~min}$, $4,8,12,16,24,36$, and $48 \mathrm{~h}$ after minipump removal. A group of rats pretreated with $\alpha$-flu $(n=8)$ were observed for somatic signs $16 \mathrm{~h}$ after minipump removal. Experimenters were blind to the drug treatment of each subject. Typical abstinence signs in mice included head shakes, paw tremors, writhing, scratching, backing, and jumping (Isola et al, 1999; Stoker et al, 2008). Rats were observed for body and head shakes, cheek tremors, eye blinks, ptosis, foot and genital licks, scratches, writhes, and gasps (Malin et al, 1992).

\section{Place Conditioning Procedure}

Mice and rats were conditioned in an apparatus as described previously (Dockstader et al, 2001; Vargas-Perez et al, 2009). Briefly, mice were conditioned in an apparatus consisting of two different environments measuring $15 \times 15 \times 15 \mathrm{~cm}$. One environment was black with a smooth Plexiglas floor that was wiped with $5 \%$ acetic acid and the other environment was white with a wire mesh floor. The boxes were separated by a removable wall that was painted with the corresponding color on each side. During preference testing, the dividing wall was removed and mice were given free access to both environments. Rats were conditioned in boxes measuring $41 \times 41 \times 38 \mathrm{~cm}$. One environment was black with a Plexiglas bottom wiped with a $3 \%$ acetic acid solution before conditioning. The other environment was white with a smooth aluminum bottom covered by a mesh grid. The test cage had black and white sides separated by a middle gray area. For preference testing, the rats were placed in the neutral gray zone and given free choice between the different environments.

Each cage was cleaned between animals and each group was fully counterbalanced. A single $10 \mathrm{~min}$ preference testing session was performed 3-5 days after the last conditioning day, when subjects were drug and withdrawal free. Behavioral testing for rats consisted of three phases: pre-exposure, conditioning, and testing. The pre-exposure phase comprised a single 20-min session in separate boxes painted gray with a gray floor. The conditioning phase comprised one to two sessions of $40 \mathrm{~min}$ each for rats and $1 \mathrm{~h}$ for mice, depending on the procedure $(\mathrm{B}, \mathrm{N}$, or $\mathrm{W}$ - see below for details). All place conditioning and testing was performed between 0830 and 1900 hours.

Procedure B (both drug and withdrawal pairing) was adapted from the method described by Bechara et al (1992). Procedure $B$ involved two pairings, the first having one environment paired to the administration of nicotine that was continuously delivered through a minipump. For the second pairing, the minipump was removed and the animal was paired to the other environment while experiencing withdrawal. The drug-paired environment was counterbalanced within groups. Before the withdrawal-paired conditioning, each mouse $(n=100)$ and rat $(n=16)$ underwent 8 and $16 \mathrm{~h}$ of abstinence from nicotine, respectively. Thus, in procedure $B$, each animal experienced the effects of nicotine in one environment and the lack of nicotine (or the effects of withdrawal) in the other environment (Figure 1b). The difference score for each animal was calculated by subtracting the time spent in the withdrawal-paired environment from the time spent in the nicotine-paired environment. This method of place conditioning (procedure $\mathrm{B}$ ) measures both the rewarding value of the drug itself and the aversiveness associated with drug withdrawal (Bechara et al, 1992).

Procedure $\mathrm{N}$ (nicotine only) was a modified place conditioning procedure for which conditioning took place in only the nicotine-paired environment of the place conditioning apparatus. As in procedure $B$, each animal was chronically nicotine treated and confined to one of the environments. On the alternate day, the minipump was removed and the animal experienced withdrawal in its home cage. Thus, in contrast to procedure $\mathrm{B}$, the mice $(n=23)$ and rats $(n=10)$ were never allowed to experience withdrawal in the other compartment of the place conditioning apparatus. The difference score for each animal was calculated by subtracting the time spent in the non-paired environment from the time spent in the nicotine-paired environment. This place conditioning method (procedure $\mathrm{N}$ ) measures the rewarding value of the drug itself (Bechara and van der Kooy, 1992).

In procedure W (withdrawal only), conditioning took place in only the withdrawal-paired environment of the place conditioning apparatus. The key difference between this procedure and procedure $\mathrm{N}$ was that withdrawal only (but not the direct effects of chronic nicotine) was paired with one compartment of the place conditioning apparatus. On the first day, each mouse $(n=60)$ and rat $(n=14)$ received a sham surgery in which the minipump was removed and replaced immediately, controlling for any effects of surgery on conditioning. For the remainder of the day, the animal was confined to its home cage. On the conditioning day, the minipump was removed and when the animal was experiencing withdrawal they were confined to one of the conditioning environments. Mice were conditioned at $4 \mathrm{~h}(n=10), 8 \mathrm{~h} \quad(n=38)$, and $12 \mathrm{~h}(n=12)$ after pump removal. Rats were conditioned at $16 \mathrm{~h}$ after pump removal. The difference score for each animal was calculated by subtracting the time spent in the non-paired environment from the time spent in the 
withdrawal-paired environment. This method of place conditioning (procedure $\mathrm{W}$ ) measures only the aversive motivational effects of drug withdrawal, separate from the rewarding value of the drug itself (Bechara and van der Kooy, 1992).

\section{Effects of $\alpha$-Flupenthixol}

Mice $(n=51)$ and rats $(n=12)$ were made nicotine dependent and conditioned according to procedure $\mathrm{B}$ or $\mathrm{W}$ as described above except that subjects were pretreated with either saline or $\alpha$-flu (Sigma-Aldrich). This DA antagonist has no motivational effects on its own at the doses and times used in this study (Laviolette and van der Kooy, 2003) and is known to antagonize both DA $D_{1}$ and $\mathrm{D}_{2}$ receptors (Creese et al, 1976). Mice $(n=12)$ were also conditioned according to procedure $\mathrm{N}$. Mice were pretreated with $0.08 \mathrm{mg} / \mathrm{kg}$ (i.p.) at $60 \mathrm{~min}$ and rats with $0.1 \mathrm{mg} / \mathrm{kg}$ (i.p.) $\alpha$-flu at $120 \mathrm{~min}$ before conditioning.

\section{Acute Nicotine Conditioning}

Previously drug naive wild-type mice $(n=62)$ were given a single dose of nicotine $(1.75 \mathrm{mg} / \mathrm{kg}$ free base, s.c.) in one environment and saline in the other environment. This dose of nicotine was expected to produce an acute aversive motivational response (Rauhut et al, 2008). The mice were conditioned in the $\mathrm{B}$ procedure in the same way as dependent and withdrawn mice (described above).

To examine the acute nicotine a-process, previously drug naive mice $(n=20)$ were conditioned immediately after nicotine administration. To examine the effect of DA system blockade on the acute nicotine a-process, an injection of $\alpha$-flu or saline was administered $1 \mathrm{~h}$ before nicotine $(n=18)$.

To examine the acute nicotine b-process, mice $(n=42)$ were conditioned $8 \mathrm{~h}$ after nicotine administration for $1 \mathrm{~h}$. To examine DA system involvement in the acute nicotine b-process, $\alpha$-flu or saline was administered $1 \mathrm{~h}$ before conditioning $(n=24$; delay) or $1 \mathrm{~h}$ before nicotine administration ( $n=18$; no delay) in separate groups of mice.

\section{Statistical Analysis}

Somatic withdrawal results were analyzed with SYSTAT software using a two-way repeated measures analysis of variance (ANOVA) at each somatic withdrawal point after dependence assessment. For conditioned place preference experiments, statistical analysis was performed using a one- or two-way ANOVA. Post hoc StudentNewman-Keuls tests or Student's $t$-tests were performed where appropriate. $p$-values $<0.05$ were considered to be significant.

\section{RESULTS}

\section{Both Rats and Mice Show Somatic Signs upon Withdrawal from Chronic Nicotine}

Discontinuing the administration of chronic nicotine after 7 days in rats and 12 days in mice produced a spontaneous somatic nicotine abstinence syndrome. The severity of this syndrome at various time points after chronic pump removal is depicted in Figure 2a for mice and Figure $2 b$ for rats, shown as mean abstinence scores taking saline as $100 \%$. A two-way repeated measures ANOVA comparing mouse abstinence scores revealed a significant dose $\times$ time interaction $\left(\mathrm{F}_{10,75}=2.761, p<0.05\right)$. Nicotine withdrawn mice showed significantly increased somatic withdrawal signs compared with saline-treated mice in both the 1.4 and $7 \mathrm{mg} / \mathrm{kg} /$ day group at $8 \mathrm{~h}$ after pump removal $(p<0.05)$, but not at $4 \mathrm{~h}(p>0.05)$ or $12 \mathrm{~h}(p>0.05)$ after pump removal. The $7 \mathrm{mg} / \mathrm{kg} /$ day nicotine dose was selected for use in subsequent mouse experiments because of the largest
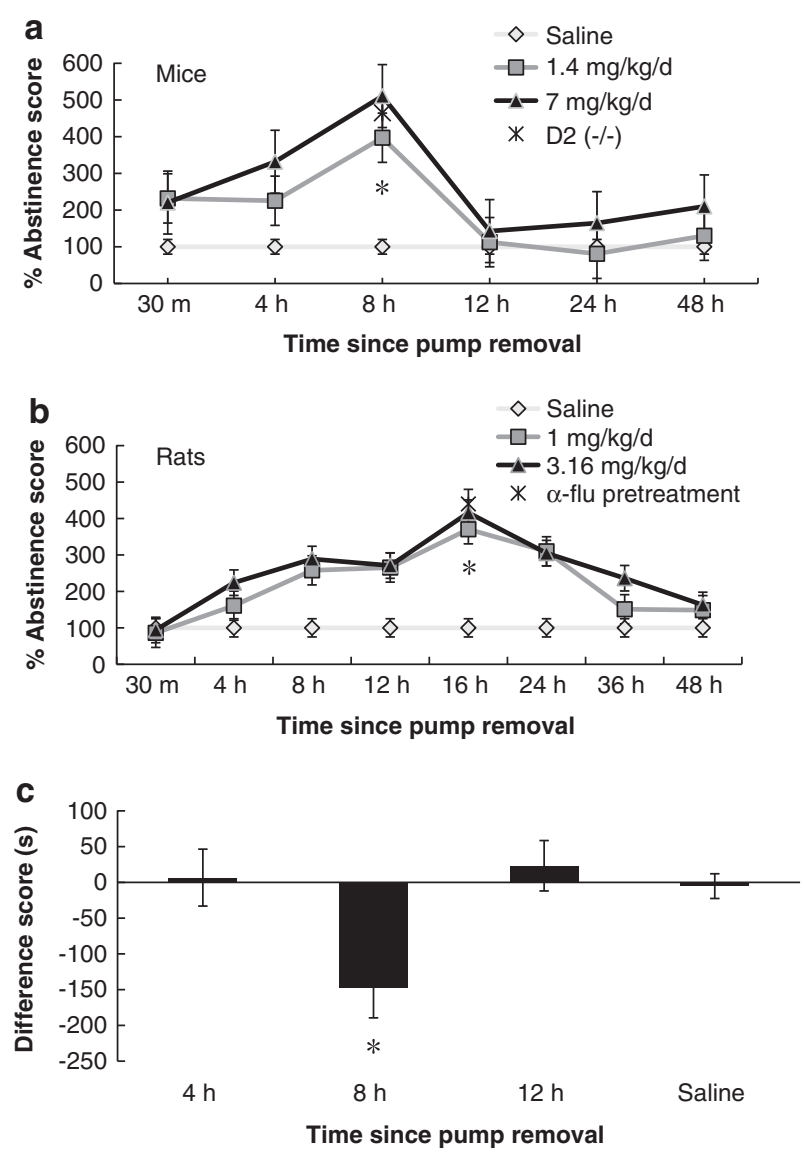

Figure 2 Time course of spontaneous nicotine somatic withdrawal (a) Somatic withdrawal signs were recorded in mice at $30 \mathrm{~min}, 4,8,12,24$, and $48 \mathrm{~h}$ after minipump removal. After 13 days of nicotine minipumps $(7 \mathrm{mg} / \mathrm{kg} /$ day $(n=6)$ and $1.4 \mathrm{mg} / \mathrm{kg} /$ day $(n=6))$, an abstinence syndrome compared with saline-treated mice $(n=6)$ was observed that peaked at $8 \mathrm{~h}$ after pump removal $(* p<0.05) . D_{2}(-1-)$ mice treated with $7 \mathrm{mg} / \mathrm{kg} /$ day nicotine $(n=6)$ observed for abstinence signs $8 \mathrm{~h}$ after pump removal showed a somatic withdrawal syndrome that did not differ from wild-type mice. (b) Somatic withdrawal signs were recorded in rats at $30 \mathrm{~min}$, $4,8,12,16,24,36$ and $48 \mathrm{~h}$ after minipump removal. After 7 days of nicotine minipumps ( $1 \mathrm{mg} / \mathrm{kg} / \mathrm{day}(n=8)$ and $3.16 \mathrm{mg} / \mathrm{kg} / \mathrm{day}(n=8))$, an abstinence syndrome compared with saline-treated rats $(n=8)$ was observed that peaked at $16 \mathrm{~h}$ after pump removal $(* p<0.05)$. Rats treated with $0.1 \mathrm{mg} / \mathrm{kg} \alpha$-flupenthixol ( $\alpha$-flu) $(n=6)$ observed for abstinence signs $16 \mathrm{~h}$ after pump removal showed a somatic withdrawal syndrome that differed from saline-treated rats $(* p<0.05)$. (c) Mice were trained in the $W$ procedure at 4,8 , and $12 \mathrm{~h}$ after pump removal at the $7 \mathrm{mg} / \mathrm{kg} /$ day chronic nicotine dose. A significant motivational effect was observed in chronic nicotine-treated mice only at the 8 -h time point $(* p<0.05)$. Data represent means \pm SEM. 
abstinence syndrome being observed with this dose at the 8-h time point.

To test whether DA signaling and the $\mathrm{D}_{2}$ receptor specifically is involved in the emergence of spontaneous nicotine withdrawal after chronic nicotine exposure, a group of $\mathrm{D}_{2}(-/-)$ mice $(n=6)$ were observed for abstinence signs at $8 \mathrm{~h}$ after removal of pumps containing the $7 \mathrm{mg} / \mathrm{kg} /$ day nicotine dose. $\mathrm{D}_{2}(-/-)$ mice showed spontaneous somatic signs of withdrawal at a similar level as wild-type mice given the $7 \mathrm{mg} / \mathrm{kg} /$ day dose of nicotine $\left(t_{10}=1.041, p>0.05\right.$; Figure 2a).

Nicotine withdrawn rats after 7 days of exposure showed the largest abstinence syndrome at $16 \mathrm{~h}$ after pump removal. A two-way repeated measures ANOVA comparing abstinence scores in rats revealed a significant dose $\times$ time interaction $\left(\mathrm{F}_{18,189}=5.740, p<0.05\right.$; Figure $\left.2 \mathrm{~b}\right)$. Somatic withdrawal signs were significantly increased compared with saline-treated rats in both the $3.15 \mathrm{mg} / \mathrm{kg} / \mathrm{day}$ group $(p<0.05)$ and $1 \mathrm{mg} / \mathrm{kg} /$ day group $(p<0.05)$ at $16 \mathrm{~h}$ after pump removal, but not at baseline before pump removal $\left(\mathrm{F}_{2,21}=0.190, p>0.05\right)$ nor after $48 \mathrm{~h}\left(\mathrm{~F}_{2,21}=2.900, p>0.05\right)$ after pump removal.

An additional group of rats $(n=8)$ pretreated with $\alpha$-flu were observed for somatic signs of nicotine withdrawal $16 \mathrm{~h}$ after pump removal. Nicotine withdrawn rats treated with $\alpha$-flu showed significant somatic withdrawal signs in comparison with saline-treated animals $\left(t_{14}=6.20, p<0.05\right.$; Figure 2b).

Chronic nicotine exposure did not noticeably affect the subjects during the exposure period (based on observations of locomotor activity, feeding patterns, and general behavior). To examine the relevance of rodent nicotine exposure to the human condition, we analyzed plasma levels of nicotine in mice treated with the $7 \mathrm{mg} / \mathrm{kg} /$ day dose and found an average of $29.9 \pm 15.5 \mathrm{ng} / \mathrm{ml}$, a result that is similar to the average maximum arterial blood concentration of human chronic smokers (range 20-40 ng/ml) (Armitage et al, 1975; Matta et al, 2007; O’Dell et al, 2006).

\section{Somatic and Affective Nicotine Withdrawal Occur Coincidentally}

To determine whether the time when maximal somatic withdrawal signs were observed corresponded to the time of motivational response in a place conditioning paradigm, chronic nicotine-treated mice were conditioned in the $\mathrm{W}$ procedure at 4 and $12 \mathrm{~h}$ after pump removal (when few somatic withdrawal signs were observed in mice) and compared with $8 \mathrm{~h}$ after pump removal (when most somatic withdrawal signs were observed in mice). Saline-treated mice conditioned at 4,8 , and $12 \mathrm{~h}$ after pump removal showed no significant difference for time of conditioning $\left(\mathrm{F}_{2,25}=0.279, p>0.05\right)$ and were therefore analyzed as one group. A two-way ANOVA showed a significant treatment $\times$ withdrawal time interaction $\left(\mathrm{F}_{2,44}=3.414, p<0.05\right.$; Figure 2c). Nicotine-treated mice showed a significant motivational effect only at the 8 -h time point $(p<0.05)$, a result that validates the use of the $8 \mathrm{~h}$ after pump removal time point as our maximal withdrawal conditioning time and suggests that somatic withdrawal coincides with motivational withdrawal over time.
Mice and Rats Show Conditioned Place Aversions to an Environment Paired with Nicotine Withdrawal

To dissociate the rewarding from the aversive motivational effects of nicotine and nicotine withdrawal in dependent subjects, we performed place conditioning using the $\mathrm{B}, \mathrm{N}$, and $\mathrm{W}$ procedures. A one-way ANOVA comparing the $\mathrm{B}, \mathrm{N}$, and $\mathrm{W}$ procedures and saline in mice showed a significant effect of chronic nicotine treatment $\left(\mathrm{F}_{3,47}=15.372, p<0.05\right.$; Figure $3 a)$. Saline-treated mice in each of the $B, N$, and $W$ procedures were not significantly different $\left(\mathrm{F}_{2,13}=0.447\right.$, $p>0.05)$ and were therefore analyzed as one group. Mice showed a significant preference for the nicotine-paired side as compared with the withdrawal-paired side in the B procedure $(p<0.05)$, showing that either nicotine is rewarding to dependent animals, or withdrawal is aversive, or both. To determine which of these motivational effects was responsible for the $\mathrm{B}$ procedure results, we used the $\mathrm{N}$ and $\mathrm{W}$ procedures, which separate the rewarding effects of a drug from the aversiveness of withdrawal (Bechara and van der Kooy, 1992). Nicotine-dependent mice showed a significant preference for the nicotine-paired side $v s$ the non-paired side in the $\mathrm{N}$ procedure $(p<0.05)$, suggesting that the presence of nicotine in a nicotine-dependent animal is rewarding. In the $\mathrm{W}$ procedure, mice showed a significant aversion to the withdrawal-paired side compared with the non-paired side $(p<0.05)$, suggesting that withdrawal from chronic nicotine is indeed aversive. To control for a bias in novelty seeking in the $\mathrm{N}$ and $\mathrm{W}$ procedures, we tested for a place preference for a novel, previously unpaired environment in saline-treated animals. Saline-treated mice did not show a preference for the novel side over a previously paired side $\left(t_{5}=0.932, p>0.05\right.$; data not shown), demonstrated that a novelty effect cannot account for the $\mathrm{N}$ and $\mathrm{W}$ procedure results.

To evaluate whether the rewarding and aversive properties of chronic nicotine would generalize to another species, we conditioned rats using the same protocols as mice. A one-way ANOVA comparing the $\mathrm{B}, \mathrm{N}$, and $\mathrm{W}$ procedures and saline in rats showed a significant effect of procedure $\left(\mathrm{F}_{3,44}=18.896, p<0.05\right.$; Figure $\left.3 \mathrm{c}\right)$. Saline-treated rats in each of the $B, N$, and $W$ procedures were not significantly different $\left(F_{2,21}=0.016, p>0.05\right)$ and were therefore analyzed as one group. Rats showed a significant preference for the nicotine-paired side as compared with the withdrawalpaired side in the $\mathrm{B}$ procedure $(p<0.05)$. In the $\mathrm{N}$ procedure, nicotine-dependent rats did not prefer the nicotine-paired or the non-paired environment $(p>0.05)$. Rats tested in the $\mathrm{W}$ procedure showed an aversion to the withdrawal-paired side compared with the non-paired side $(p<0.05)$, suggesting that withdrawal from chronic nicotine is indeed motivationally aversive. Results from the $\mathrm{N}$ and $\mathrm{W}$ procedures in rats suggest that the motivational effect in the $\mathrm{B}$ procedure may be attributable primarily to an aversive response to nicotine withdrawal.

\section{Acute Nicotine Stimulates Opposing Motivational Processes}

We next examined whether acute nicotine would elicit opposing motivational processes in previously drug naive mice, using the $\mathrm{B}$ procedure and identical conditioning 

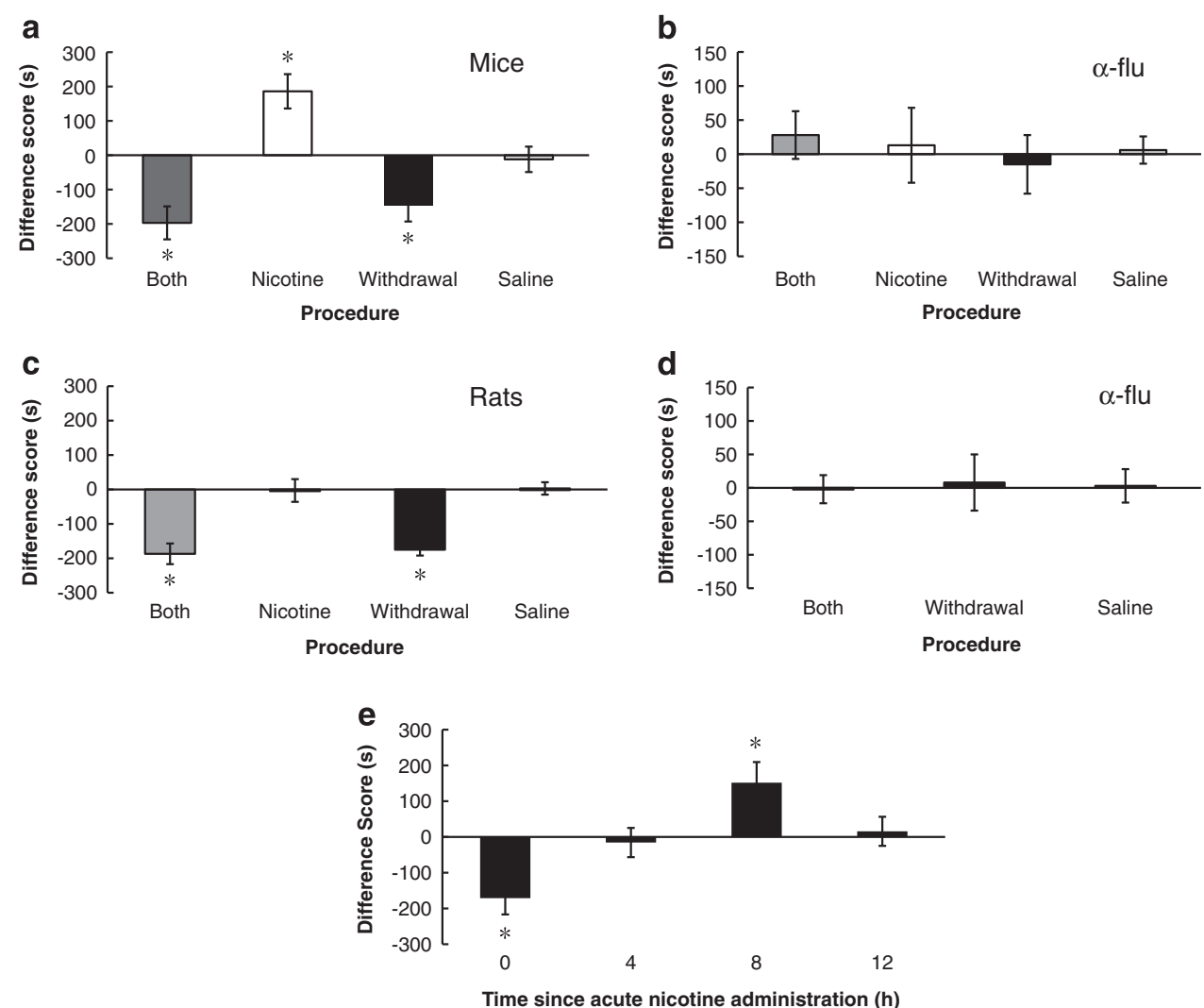

Figure 3 The opponent processes of chronic and acute nicotine and the effect of dopamine (DA) antagonism. (a) Separation of the rewarding effects of chronic nicotine from the aversive effects of withdrawal in nicotine-dependent mice, as revealed by a modified place conditioning paradigm for assessing the rewarding effects of nicotine only (Nicotine procedure; $n=11$ ), the aversive effects of nicotine withdrawal (Withdrawal procedure; $n=\mid 4$ ), or both the rewarding effects of nicotine and the aversive effects of withdrawal (Both procedure; $n=15$ ). Nicotine-dependent mice conditioned in all three procedures showed a significant motivational response as compared with saline-treated animals $(* p<0.05)$. (b) $\alpha$-flu $(0.08 \mathrm{mg} / \mathrm{kg}$, i.p.) pretreatment attenuated the motivational response in each of the B $(n=16), N(n=12)$, and $W(n=14)$ procedures, and had no motivational effect in saline-treated mice. (c) Separation of the rewarding effects of chronic nicotine from the aversive effects of withdrawal in nicotine-dependent rats. Significant effects were observed in the Both $(n=8)$ and Withdrawal $(n=10)$ procedures, but not in the Nicotine $(n=10)$ procedure $(* p<0.05)$ as compared with saline. (d) $\alpha$-flu $(0.1$ mg/kg) pretreatment attenuated the Both $(n=8)$ and Withdrawal $(n=4)$ effects. (e) Previously drug naive mice $(n=13)$ administered a single dose of nicotine $(1.75 \mathrm{mg} / \mathrm{kg}$, s.c.) and conditioned immediately $(0 \mathrm{~h})$ in the B procedure showed a significant conditioned place aversion for the nicotine-paired environment $(* 0.05)$. Mice $(n=14)$ conditioned $8 \mathrm{~h}$ after acute nicotine administration showed a significant preference for the nicotine-paired environment $(* p<0.05)$. Mice conditioned 4 or $12 \mathrm{~h}$ after nicotine administration showed no significant effect. Data represent means \pm SEM.

times to those used above in nicotine dependent and withdrawn mice. We administered a single dose of nicotine $(1.75 \mathrm{mg} / \mathrm{kg}$, s.c.) and conditioned separate groups of mice immediately $(0 \mathrm{~h})$ and 4,8 , and $12 \mathrm{~h}$ after nicotine administration. A one-way ANOVA showed a significant effect of conditioning time $\left(\mathrm{F}_{3,36}=7.827, p<0.05\right.$; Figure $\left.3 \mathrm{e}\right)$. When drug naive mice were given an acute dose of nicotine and conditioned immediately after nicotine administration, they showed a significant conditioned place aversion $(p<0.05)$. The opponent process theory of motivation suggests that an acute aversive effect of nicotine (a-process) will set up a longer lasting opponent b-process that should manifest as a rewarding response to the environment paired with $8 \mathrm{~h}$ of abstinence from acute aversive nicotine. We observed a significant preference for the nicotine-paired environment at $8 \mathrm{~h}$ after nicotine administration $(p<0.05)$. When mice were conditioned 4 and $12 \mathrm{~h}$ after acute nicotine administration, they showed no significant motivational effect $(p>0.05)$. These results show that an acute aversive dose of nicotine stimulates two separate opposing motivational effects: an aversive response when mice are conditioned immediately after nicotine administration and a rewarding response when mice are conditioned $8 \mathrm{~h}$ after nicotine administration.

\section{DA Receptor Blockade Attenuates Chronic Nicotine Withdrawal Aversions}

We examined whether the DA system mediates the motivational responses to nicotine and withdrawal in the nicotine-dependent state. Mice were given $\alpha$-flu $1 \mathrm{~h}$ before conditioning in the $\mathrm{B}, \mathrm{N}$, and $\mathrm{W}$ procedures. A two-way ANOVA using procedure (B, N, W, or saline) and pretreatment ( $\alpha$-flu or saline) as independent factors showed a procedure $\times$ pretreatment interaction $\left(\mathrm{F}_{3,106}=11.593\right.$, $p<0.05$; Figure $3 b$ ). Saline-treated mice in each of the $B$, $\mathrm{N}$, and $\mathrm{W}$ procedures were not significantly different $\left(\mathrm{F}_{2,19}=0.043, p>0.05\right)$ and were therefore analyzed as one group. DA receptor blockade prevented the conditioned motivational effect in the $\mathrm{B}, \mathrm{N}$, and $\mathrm{W}$ procedures $(p>0.05)$. Mice conditioned in the B procedure with $\alpha$-flu in one environment and saline in the other environment showed no motivational preference $(p>0.05)$, showing that the dose 
of $\alpha$-flu used in the present experiments does not have any motivational effects on its own.

Consistent results were obtained in rats when they were pretreated with $\alpha$-flu $1 \mathrm{~h}$ before conditioning in the $\mathrm{B}$ and $\mathrm{W}$ procedures. A two-way ANOVA using procedure (B, $\mathrm{W}$, or saline) and pretreatment ( $\alpha$-flu or saline) as independent factors showed a procedure $\times$ pretreatment interaction $\left(\mathrm{F}_{2,61}=9.174, p<0.05\right.$; Figure $\left.3 \mathrm{~d}\right)$. Saline-treated rats in the $\mathrm{B}$ and $\mathrm{W}$ procedures were not significantly different $\left(\mathrm{F}_{1,14}=0.032, \quad p>0.05\right)$ and were therefore analyzed as one group. We did not include a group of rats pretreated with $\alpha$-flu in the $\mathrm{N}$ procedure, as no motivational effect was observed in the dependent group (Figure 3c). DA receptor blockade prevented the conditioned motivational effect in the $\mathrm{B}$ and $\mathrm{W}$ procedures $(p>0.05)$. The results from both rats and mice receiving $\alpha$-flu pretreatment in the $\mathrm{W}$ procedure show that the DA system is mediating the aversive response to withdrawal after chronic nicotine.

\section{Dopaminergic Signaling Specifically Mediates Chronic Nicotine Withdrawal Aversions}

To further analyze dopaminergic mediation of the rewarding effects of nicotine $v s$ the aversiveness of withdrawal in nicotine-dependent animals, we gave $\alpha$-flu to mice in either the nicotine-paired or withdrawal-paired environment in the $\mathrm{B}$ procedure and observed the effect on the aversive motivational response after $8 \mathrm{~h}$ of abstinence from chronic nicotine. A one-way ANOVA showed a significant effect of treatment $\left(\mathrm{F}_{2,33}=10.941, p<0.05\right.$; Figure $\left.4 \mathrm{a}\right)$. Mice given saline on both conditioning days showed an aversive motivational response to chronic nicotine withdrawal, as observed earlier (saline; $p<0.05$ ). When mice were pretreated with $\alpha$-flu on the nicotine-paired side and given saline on the withdrawal-paired side, a preference for the nicotine-paired environment over the withdrawal-paired environment was observed (no delay; $p<0.05$ ). Mice that received the opposite treatment ( $\alpha$-flu on the withdrawalpaired side and saline on the nicotine-paired side) did not show an aversive response to withdrawal from chronic nicotine (delay; $p>0.05$ ). These results suggest that the dopaminergic system mediates the aversive response to withdrawal from chronic nicotine.

\section{Dopamine Receptor Antagonism Does Not Block the Rewarding Motivational Response $8 \mathrm{~h}$ after Acute Nicotine}

We next analyzed whether the DA system mediates the positive response observed $8 \mathrm{~h}$ after acute nicotine in the same way as it does the aversive response observed $8 \mathrm{~h}$ after chronic nicotine. The immediate aversive effects of acute nicotine are blocked by pretreatment with $\alpha$-flu in rats (Laviolette and van der Kooy, 2003). We observed that the immediate aversive response to acute nicotine in mice was blocked by $\alpha$-flu pretreatment $\left(t_{6}=1.785, p>0.05\right.$; data not shown). To analyze the effect of DA antagonism on the rewarding motivational response $8 \mathrm{~h}$ after acute nicotine, we administered $\alpha$-flu $1 \mathrm{~h}$ before conditioning for either the immediate aversive or the delayed rewarding effect, similar to the procedure followed with nicotine-dependent mice. A
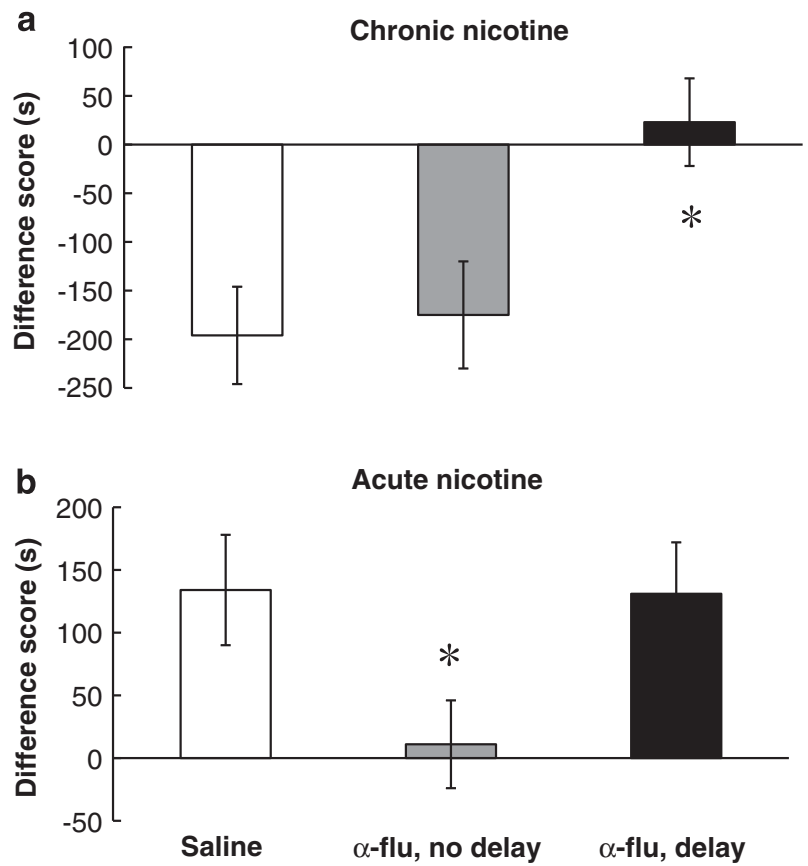

Figure 4 Dopaminergic signaling differentially mediates the opponent motivational process after acute and chronic nicotine. (a) Mice chronically treated with nicotine $(7 \mathrm{mg} / \mathrm{kg} /$ day $)$ and pretreated with saline $(n=8)$ show a conditioned place aversion to the withdrawal-paired environment in the B procedure. $\alpha$-flu $(0.08 \mathrm{mg} / \mathrm{kg}$, i.p.) given I h before conditioning during chronic nicotine administration (no delay; $n=\mid I$ ) did not prevent the aversive response from occurring. However, $\alpha$-flu given before conditioning after $8 \mathrm{~h}$ of abstinence from chronic nicotine (delay) blocked the aversive response from occurring (* $<0.05$ vs saline). (b) Previously drug naive mice given acute nicotine ( $1.75 \mathrm{mg} / \mathrm{kg}$, s.c.), pretreated with saline $(n=14)$, and conditioned after $8 \mathrm{~h}$ of abstinence from nicotine show a preference for the acute withdrawal-paired environment. $\alpha$-flu $(0.08 \mathrm{mg} / \mathrm{kg}$, i.p.) administered before acute nicotine (no delay; $n=12$ ) prevented the rewarding response from occurring (* $p<0.05$ vs saline). However, $\alpha$-flu given before conditioning after $8 \mathrm{~h}$ of abstinence from acute nicotine (delay; $n=16$ ) did not prevent the occurrence of the rewarding response. Data represent means \pm SEM

one-way ANOVA showed a significant effect of treatment $\left(\mathrm{F}_{2,39}=4.068, p<0.05\right.$; Figure $\left.4 \mathrm{~b}\right)$. Mice pretreated with saline showed a preference for an environment paired with $8 \mathrm{~h}$ of abstinence from acute nicotine, as observed earlier (Saline; $p<0.05$ ). However, $\alpha$-flu pretreatment before acute nicotine prevented the later occurring rewarding response (no delay; $p>0.05$ ). This result suggests that the immediate aversive response to acute nicotine is required for the delayed rewarding response to occur. Mice treated with $\alpha$-flu before conditioning for the delayed rewarding response showed a similar conditioned place preference to saline-treated mice (delay; $p<0.05$ ). These results show that dopaminergic signaling is required for conditioning to the immediate aversive effect of acute nicotine, but not the delayed rewarding effect occurring $8 \mathrm{~h}$ after acute nicotine.

\section{The Dopamine $\mathrm{D}_{2}$ Receptor Mediates the Aversive Response to Withdrawal from Chronic Nicotine}

The behavior of male $\mathrm{D}_{2}(+/+)$ wild type and $\mathrm{D}_{2}(-/-)$ littermate mice was examined using the $\mathrm{N}$ and $\mathrm{W}$ place 


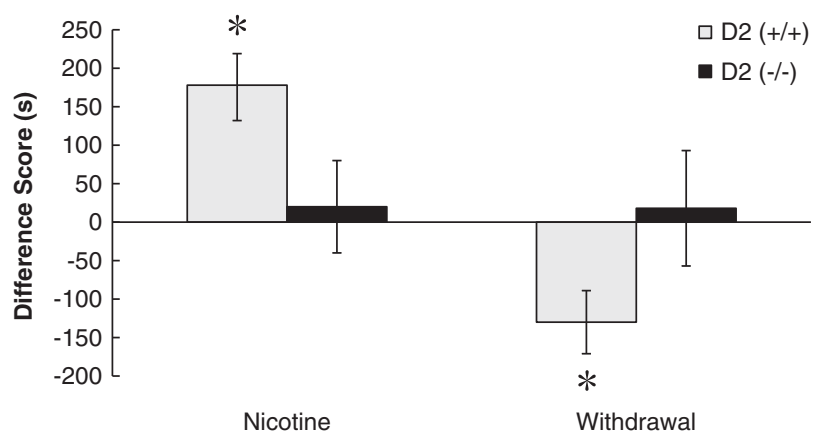

Procedure

Figure 5 The $D A D_{2}$ receptor mediates the aversive response to chronic nicotine withdrawal. Wild-type mice $\left(D_{2}(+/+) ; n=10\right)$ conditioned in procedure $\mathrm{N}$ showed a preference for chronic nicotine that was not present in $D_{2}(-/-)$ mice $\left(n=7 ;{ }^{*} p<0.05\right)$. $D_{2}(-/-)$ mice $(n=13)$ conditioned in procedure $W$ did not show nicotine aversions whereas $D_{2}(+/+)$ mice $(n=14)$ showed normal aversions to chronic nicotine withdrawal $(*<0.05)$. Data represent means \pm SEM.

conditioning procedures to determine the role of the $\mathrm{DA} \mathrm{D}_{2}$ receptor in mediating the motivational response to chronic nicotine and withdrawal. A two-way ANOVA using genotype and procedure ( $\mathrm{N}$ or $\mathrm{W}$ ) showed a genotype $\times$ procedure interaction $\left(\mathrm{F}_{2,42}=20.260, p<0.05\right.$; Figure 5). Wild-type mice conditioned in the $\mathrm{N}$ procedure showed a significant preference for an environment paired with chronic nicotine $(p<0.05)$ that was not shown by $\mathrm{D}_{2}(-/$ $-)$ mice $(p>0.05) \cdot \mathrm{D}_{2}(+/+)$ mice conditioned in the $\mathrm{W}$ procedure showed a significant aversion to an environment paired with withdrawal from chronic nicotine $(p<0.05)$, similar to the wild-type mice in previous experiments. However, $\mathrm{D}_{2}(-/-)$ mice did not show an aversion to withdrawal $(p>0.05)$, indicating that the $\mathrm{D}_{2}$ receptor mediates the aversive response to withdrawal from chronic nicotine.

\section{DISCUSSION}

Understanding the neurobiological substrates mediating the motivational response experienced by smokers during nicotine withdrawal has important implications for improving smoking cessation. We show here that dopaminergic signaling at the $\mathrm{D}_{2}$ receptor mediates affective but not somatic nicotine withdrawal. Moreover, we have dissociated the role of dopaminergic signaling in the opponent motivational processes of acute and chronic nicotine. Dopaminergic signaling, specifically at the $\mathrm{D}_{2}$ receptor, is required for the delayed but not the immediate motivational response to chronic nicotine in dependent subjects. In contrast, dopaminergic signaling is required for the immediate but not the delayed motivational response to acute nicotine in non-dependent subjects.

Somatic signs observed in the present experiments resemble those described earlier in mice (Isola et al, 1999; Stoker et al, 2008) and rats (Epping-Jordan et al, 1998; Malin et al, 1992; Watkins et al, 2000); however, the time course of peak nicotine somatic withdrawal differs. The use of a variety of time points in our measurements of somatic withdrawal symptoms allowed us to find the most appropriate time for withdrawal motivation studies in both mice and rats. Although the dose used in mice $(7 \mathrm{mg} / \mathrm{kg} /$ day) and rats $(3.15 \mathrm{mg} / \mathrm{kg} /$ day $)$ exceeds the amount of nicotine smoked by the heaviest smokers of high-yield cigarettes (Armitage et al, 1975; Epping-Jordan et al, 1998), it is important to consider that rats and mice have much higher metabolic and drug clearance rates (Matta et al, 2007) than humans. Furthermore, plasma levels of nicotine measured presently were similar to those observed in humans and measured in previous rodent studies (Guillem et al, 2005; O'Dell et al, 2006). We showed that nicotine somatic withdrawal coincides with affective withdrawal, such that the largest abstinence syndrome in both mice and rats occurs when the aversive response to withdrawal can be conditioned in the place preference paradigm. Dopaminergic signal disruption by $\alpha$-flu pretreatment or genetic deletion of the $\mathrm{D}_{2}$ receptor blocked the motivational response to affective nicotine withdrawal but not the somatic signs of withdrawal. These results suggest that somatic and motivational withdrawal occur coincidentally, but are not causally related, and that somatic withdrawal is not DA-mediated. Similarly, motivational withdrawal from opiates can be blocked without attenuating somatic withdrawal signs (Bechara et al, 1995), lending support to the idea that somatic withdrawal signs do not necessarily reflect the motivational effect of withdrawal (Watkins et al, 2000).

Although self-administration more closely models human nicotine intake (Rose and Corrigall, 1997), separating drug motivation due to the rewarding effects of nicotine or the alleviation of withdrawal is more easily performed using a place conditioning procedure (Mucha et al, 1982). Our place conditioning experiments showed that nicotine withdrawal is aversive in both dependent mice and rats. Furthermore, results from the $\mathrm{N}$ and $\mathrm{W}$ procedures in rats suggest that the motivational effect in the B procedure may be attributable primarily to an aversive response to nicotine withdrawal, and that the motivational effects observed in the $\mathrm{N}$ procedure in mice might reflect the ability of nicotine to overcome the aversiveness of withdrawal. During preference testing, although somatic signs of withdrawal are not observed, it is possible that the animals seek nicotine to relieve the negative emotional state of protracted abstinence. It is also possible that during $\mathrm{N}$ procedure conditioning, although the animal is not in withdrawal, the opponent process is activated because of the development of some tolerance to the effects of nicotine. This tolerance after chronic exposure could decrease the efficacy of nicotine, then the animal would seek nicotine (or an environment paired with nicotine) to compensate for the decreased reinforcing effect. Nicotine reward in dependent animals has been previously demonstrated in conditioned place preference (Acquas et al, 1989; Sellings et al, 2008; Wilkinson and Bevins, 2008), self administration (Tammimaki et al, 2008) and ICSS (Kenny and Markou, 2001) paradigms, however, the $\mathrm{N}$ place conditioning procedure used in the present experiments was not sensitive enough to measure the rewarding effect of nicotine in dependent rats. An alternative hypothesis would be that the dose of nicotine (compared with mice) used in the present experiments was not sufficient to produce a motivational response, and that a higher dose of nicotine in rats would elicit a preference for the nicotine-paired environment in the $\mathrm{N}$ procedure. 
We showed that dopaminergic signaling through activation of $\mathrm{D}_{2}$ receptors is critical for the expression of chronic nicotine withdrawal aversions. It is unlikely that the present results are because of a learning deficit in $\mathrm{D}_{2}(-/-)$ mice as these mice can learn morphine (Dockstader et al, 2001) and ethanol place preferences (Ting-A-Kee et al, 2009). This result confirms previous work showing that $D_{1}$ and $D_{2}$ antagonists block conditioned aversions to nicotine withdrawal using pharmacologically precipitated withdrawal (Laviolette et al, 2008) and further extends these findings to spontaneous withdrawal, which more closely models the human condition.

The opponent process theory of motivation (Solomon and Corbit, 1974) postulates that any motivational stimulus activates two opposing motivational processes, the aprocess having a fast onset and offset and the b-process being slower to start, longer lasting and occurring in an opposite direction (Ettenberg, 2004; Koob and Le Moal, 2008; Koob et al, 1989). We have shown that an aversive dose of nicotine will act as a negative motivational stimulus in previously drug naive mice that will manifest as a negative a-process, in turn causing the activation of a delayed positive b-process. In nicotine-dependent animals, chronic nicotine will act as a rewarding motivational stimulus that will manifest as a positive a-process, in turn causing the activation of a delayed aversive b-process during withdrawal. We showed that signaling at dopaminergic receptors is required for the immediate aversive response (a-process) but not for the delayed rewarding effect after acute nicotine (b-process). In nicotine-dependent animals, we showed that signaling at dopaminergic receptors is required for the delayed aversive response (b-process) but not for the immediate rewarding response after chronic nicotine (a-process).

The immediate aversive response to nicotine in previously drug naive mice could be due to centrally and/or peripherally mediated effects. Indeed, conditioned place aversions to acute nicotine could be due to peripheral effects because nicotine is known to induce nausea (Perkins et al, 2008). However, conditioned place aversions to acute nicotine have been shown after intra-cerebral administration (Laviolette and van der Kooy, 2003). Furthermore, nicotine given peripherally has centrally mediated effects on DA release (Seppa et al, 2000). Therefore, it is unlikely that the acute aversive motivational response is simply due to nausea or another peripheral effect.

The role of the dopaminergic and TPP systems in the opponent motivational effects produced by nicotine bears striking resemblance to those produced by opiates. The aversive a-process is DA mediated in both acute opiate (Zito et al, 1988) and acute nicotine motivation, as shown presently. The rewarding a-process for acute opiates (Bechara et al, 1992) and acute nicotine are TPP mediated (Laviolette et al, 2002). We have shown that the rewarding b-process for acute nicotine is not DA mediated, which resembles the DA-independent acute aversive b-process for opiates (Bechara et al, 1992). Although the TPP appears to be a good candidate to mediate the acute b-process in both nicotine and opiate motivation, it was recently suggested that the TPP does not mediate the acute opiate b-process (Vargas-Perez et al, 2009). However, TPP involvement in the acute nicotine b-process cannot be completely ruled out as the acute nicotine b-process is rewarding and TPP involvement in acute nicotine reward has been previously demonstrated (Laviolette et al, 2002).

Results from this study showed that nicotine given acutely in a previously drug naive animal elicited a DA-mediated aversion in a place conditioning paradigm, whereas other groups have shown DA-dependent acute nicotine reward (Acquas et al, 1989; Lecca et al, 2006; Merlo Pich et al, 1999; Pak et al, 2006; Sellings et al, 2008; Spina et al, 2006). Acute nicotine administered directly into the brain produces both rewarding and aversive effects (Laviolette et al, 2002; Sellings et al, 2008) that can be segregated within the nucleus accumbens (Sellings et al, 2008). Therefore, it is not surprising that different groups have reported that different paradigms (place conditioning $v s$ self-administration) or routes of nicotine administration (intracerebral, subcutaneous, and intravenous) produce differences in the direction of the observed motivational response.

It is possible that nicotine intake may occur during withdrawal to restore previous levels of dopaminergic signaling in the dependent user's brain and therefore to blunt the negative experience of withdrawal. The $\mathrm{N}$ procedure results in mice may be due to the ability of nicotine to alleviate withdrawal. In support of this idea are the present data showing that the motivational response observed in the $\mathrm{N}$ and $\mathrm{W}$ procedures do not add to give the B (both) motivational effect. The argument then follows that nicotine is not actually rewarding in dependent animals, and the rewarding effect observed in mice conditioned in the $\mathrm{N}$ procedure is simply an alleviation of the aversiveness of withdrawal. Furthermore, when dopaminergic signaling was blocked during withdrawal-paired conditioning but left intact during nicotine-paired conditioning in the $\mathrm{B}$ procedure, no motivational response was observed. When the opposite experiment was performed, in which the DA system was blocked during nicotine-paired conditioning but left intact during withdrawal-paired conditioning, a conditioned place aversion to the withdrawal-paired environment was observed. These results suggest that nicotine motivation in nicotine dependent and withdrawn animals is driven by a DA-dependent aversion to nicotine withdrawal.

Dopaminergic signaling after nicotine administration is a complex phenomenon involving tonic and phasic DA activity (Rice and Cragg, 2004; Zhang and Sulzer, 2004; Zhang et al, 2009). Withdrawal from nicotine changes the activity of DA neurons in the VTA and the release of DA in the nucleus accumbens (Hildebrand et al, 1998; Rada et al, 2001; Liu and Jin, 2004), leading to a change in the specific pattern of DA signaling at the postsynaptic level. We hypothesize that the aversive motivational response to withdrawal from chronic nicotine is mediated by a specific pattern of DA signaling at the receptor resulting from changes in the pattern of DA release in the nucleus accumbens during withdrawal (Hildebrand et al, 1998; Rada et al, 2001; Rahman et al, 2004). We pharmacologically and genetically modified the dopaminergic signaling pattern that occurs during nicotine withdrawal and blocked the negative affective component of withdrawal. DA receptor antagonism caused a decrease in DA signaling, thereby blocking the pattern of DA firing that signals withdrawal. This change in DA signaling blocked the expression of withdrawal aversions. Administration of 
nicotine to a withdrawn subject relieves the aversiveness of withdrawal (Stolerman and Shoaib, 1991), presumably because nicotine activates nicotinic receptors on DA neurons in the VTA, causing DA release (Nisell et al, 1994; Gutkin et al, 2006). This activation of DA neurons would obscure the specific pattern of DA firing that signals aversive withdrawal. Taken together, these results suggest that withdrawal from nicotine produces a specific pattern of DA signaling that mediates the aversive motivational effects of nicotine withdrawal.

This study suggests that dopaminergic signaling is necessary for the opponent motivational response to nicotine in dependent rodents, but not in non-dependent animals. Further, signaling at the $\mathrm{D}_{2}$ receptor is critical in mediating withdrawal aversions in nicotine-dependent animals. These results suggest that different neurobiological substrates mediate the opponent motivational process for nicotine in drug-dependent and non-dependent animals and that the alleviation of nicotine withdrawal primarily may be driving nicotine motivation in dependent animals. These findings may have implications in understanding motivational processes in dependent smokers and may therefore inform targeted drug development in this population.

\section{ACKNOWLEDGEMENTS}

We thank Dr Olivier George and the reviewers for their outstanding assistance with the preparation of this paper. We also thank the van der Kooy laboratory technicians and the Division of Comparative Medicine staff for their assistance throughout the experiments. This research was supported by CIHR grants and a Canadian Tobacco Control Research Initiative (CTCRI) student research grant.

\section{DISCLOSURE}

Dr Rachel F Tyndale is a shareholder in Nicogen Research Inc., a company focused on the development of novel smoking cessation treatment approaches. None of the data contained in this paper alter or improve any commercial aspect of Nicogen and no Nicogen funds were used in this work. Taryn Grieder, Laurie Sellings, Hector Vargas-Perez, Ryan Ting-A-Kee, Eric C Siu, and Derek van der Kooy declare that no financial support has been received from any individual or corporate entity for research or professional service, and there are no personal financial holdings that could be perceived as constituting a potential conflict of interest.

\section{REFERENCES}

Acquas E, Carboni E, Leone P, Di Chiara G (1989). SCH 23390 blocks drug-conditioned place-preference and place-aversion: anhedonia (lack of reward) or apathy (lack of motivation) after dopamine-receptor blockade? Psychopharmacology 99: 151-155.

Allen SS, Bade T, Hatsukami D, Center B (2008). Craving, withdrawal, and smoking urges on days immediately prior to smoking relapse. Nicotine Tob Res 10: 35-45.

Armitage AK, Dollery DT, George CF, Houseman TH, Lewis PJ, Turner DM (1975). Absorption and metabolism of nicotine from cigarettes. Br Med J 4: 313-316.
Bechara A, Harrington F, Nader K, van der Kooy D (1992). Neurobiology of motivation: double dissociation of two motivational mechanisms mediating opiate reward in drug-naive versus drug dependent animals. Behav Neurosci 106: 798-807.

Bechara A, Nader K, van der Kooy D (1995). Neurobiology of withdrawal motivation: evidence for two separate aversive effects produced in morphine-naive versus morphine-dependent rats by both naloxone and spontaneous withdrawal. Behav Neurosci 109: 91-105.

Bechara A, van der Kooy D (1992). A single brain stem substrate mediates the motivational effects of both opiates and food in nondeprived rats but not in deprived animals. Behav Neurosci 106: 351-363.

Bruijnzeel AW, Markou A (2005). Decreased sensitivity to the effects of dopamine D1-like, but not D2-like, receptor antagonism in the posterior hypothalamic region/anterior ventral tegmental area on brain reward function during chronic exposure to nicotine in rats. Brain Res 1058: 91-100.

Creese I, Burt D, Snyder S (1976). Dopamine receptor-binding predicts clinical and pharmacological potencies of anti-schizophrenic drugs. Science 92: 481-483.

Damaj MI, Kao W, Martin BR (2003). Characterization of spontaneous and precipitated nicotine withdrawal in the mouse. J Pharmacol Exp Ther 307: 526-534.

Di Chiara G, Bassareo V (2007). Reward system and addiction: what dopamine does and doesn't do. Curr Opin Pharmacol 7: 69-76.

Dockstader CL, Rubinstein M, Grandy DK, Low MJ, van der Kooy D (2001). The D2 receptor is critical in mediating opiate motivation only in opiate-dependent and withdrawn mice. Eur $J$ Neurosci 13: 995-1001.

Epping-Jordan MP, Watkins SS, Koob GF, Markou A (1998). Dramatic decreases in brain reward function during nicotine withdrawal. Nature 393: 76-79.

Ettenberg A (2004). Opponent process properties of self-administered cocaine. Neurosci Biobehav Rev 27: 721-728.

Fehr C, Yakushev I, Hohmann N, Buchholz H-G, Landvogt C, Deckers $\mathrm{H}$ et al (2008). Association of low striatal dopamine D2 receptor availability with nicotine dependence similar to that seen with other drugs of abuse. Am J Psychiatry 165: 507-514.

George O, Ghozland S, Azar MR, Cottone P, Zorrilla EP, Parsons LH et al (2007). CRF-CRF 1 system activation mediates withdrawal-induced increases in nicotine self-administration in nicotine-dependent rats. Proc Natl Acad Sci USA 104: 17198-17203.

Guillem K, Vouillac C, Azar MR, Parsons LH, Koob GF, Cador M et al (2005). Monoamine oxidase inhibition dramatically increases the motivation to self-administer nicotine in rats. J Neurosci 25: 8593-8600.

Gutkin BS, Dehaene S, Changeux JP (2006). A neurocomputational hypothesis for nicotine addiction. Proc Natl Acad Sci USA 103: $1106-1111$.

Hildebrand BE, Nomikos GG, Hertel P, Schilstrom B, Svensson TH (1998). Reduced dopamine output in the nucleus accumbens but not in the medial prefrontal cortex in rats displaying a mecamylamine-precipitated nicotine withdrawal syndrome. Brain Res 779: 214-225.

Isola R, Vogelsberg $\mathrm{V}$, Wemlinger TA, Neff $\mathrm{NH}$, Hadjiconstantinou $M$ (1999). Nicotine abstinence in the mouse. Brain Res 850: 189-196.

Kelly MA, Rubinstein M, Asa S, Zhang G, Saez C, Bunzow JR et al (1997). Pituitary lactotroph hyperplasia and chronic hyperprolactinemia in dopmaine D2 receptor-deficient mice. Neuron 19: 103-113.

Kenny PJ, Markou A (2001). Neurobiology of the nicotine withdrawal syndrome. Pharmacol Biochem Behav 70: 531-549.

Koob GF, Le Moal M (1997). Drug abuse: hedonic homeostatic dysregulation. Science 278: 52-58. 
Koob GF, Le Moal M (2001). Drug addiction, dysregulation of reward, and allostasis. Neuropsychopharmacol 24: 97-129.

Koob GF, Le Moal M (2008). Addiction and the brain antireward system. Annu Rev Psychol 59: 29-53.

Koob GF, Stinus L, Le Moal M, Bloom FE (1989). Opponent process theory of motivation: neurobiological evidence from studies of opiate dependence. Neurosci Biobehav Rev 13: 135-140.

Lanca AJ, Adamson KL, Coen KM, Chow BL, Corrigall WA (2000). The pedunculopontine tegmental nucleus and the role of cholinergic neurons in nicotine self-administration in the rat: a correlative neuro anatomical and behavioral study. Neuroscience 96: 735-742.

Laviolette SR, Alexson TO, van der Kooy D (2002). Lesions of the tegmental pedunculopontine nucleus block the rewarding effects and reveal the aversive effects of nicotine in the ventral tegmental area. J Neurosci 22: 8653-8660.

Laviolette SR, Lauzon NM, Bishop SF, Sun N, Tan H (2008). Dopamine signaling through D1-like versus D2-like receptors in the nucleus accembens core versus shell differentially modulates nicotine reward sensitivity. J Neurosci 28: 8025-8033.

Laviolette SR, van der Kooy D (2003). Blockade of mesolimbic dopamine transmission dramatically increases sensitivity to the rewarding effects of nicotine in the ventral tegmental area. $\mathrm{Mol}$ Psychiatry 8: 50-59.

Laviolette SR, van der Kooy D (2004). The neurobiology of nicotine addiction: bridging the gap from molecules to behaviour. Nat Rev Neurosci 5: 55-65.

Lecca D, Cacciapaglia F, Valentini V, Gronli J, Spiga S, Di Chiara G (2006). Preferential increase of extracellular dopamine in the rat nucleus accumbens shell as compared to that in the core during acquisition and maintenance of intravenous nicotine self-administration. Psychopharmacology 184: $435-446$.

Liu ZH, Jin WQ (2004). Decrease of ventral tegmental area dopamine neuronal activity in nicotine withdrawal rats. Neuroreport 15: 1479-1481.

Malin DH, Lake JR, Newlin-Maultsby P, Roberts LK, Lanier JG, Carter VA et al (1992). Rodent model of nicotine abstinence syndrome. Pharmacol Biochem Behav 43: 779-784.

Malin DH, Lake JR, Smith TD, Khambati HN, Meyers-Paal RL, Montellano AL et al (2006). Bupropion attenuates nicotine abstinence syndrome in the rat. Psychopharmacology 184: 494-503.

Mansvelder HD, McGehee DS (2001). Cellular and synaptic mechanisms of nicotine addiction. Neuron 33: 905-919.

Matta SG, Balfour DJ, Benowitz NL, Boyd RT, Buccafusco JJ, Caggiula AR et al (2007). Guidelines on nicotine dose selection for in vivo research. Psychopharmacology 190: 269-319.

Merlo Pich E, Chiamulera C, Carboni L (1999). Molecular mechanisms of the positive reinforcing effect of nicotine. Behav Pharmacol 10: 587-596.

Mucha RF, van der Kooy D, O’Shaughnessy M, Bucenieks P (1982). Drug reinforcement studied by use of place conditioning in rat. Brain Res 243: 91-105.

Nisell M, Nomikos GG, Svensson TH (1994). Systemic nicotineinduced dopamine release in the rat nucleus accumbens is regulated by nicotinic receptors in the ventral tegmental area. Synapse 16: 36-44.

O'Dell LE, Bruijnzeel AW, Smith RT, Parsons LH, Merves ML, Goldberger BA et al (2006). Diminished nicotine withdrawal in adolescent rats: implications for vulnerability to addiction. Psychopharm 186: 612-619.

Pak AC, Ashby CR, Heibreder CA, Pilla M, Gilbert J, Xi Z-X et al (2006). The selective dopamine $\mathrm{D}_{3}$ receptor antagonist SB-277011A reduces nicotine-enhanced brain reward and nicotine-paired environmental cue functions. Int J Neuropsychopharmacol 9: 585-602.
Perkins KA, Lerman C, Coddington S, Karelitz JL (2008). Association of retrospective early smoking experiences with prospective sensitivity to nicotine via nasal spray in nonsmokers. Nicotine Tob Res 10: 1335-1345.

Picciotto MR, Corrigall WA (2002). Neuronal systems underlying behaviors related to nicotine addiction: neural circuits and molecular genetics. J Neurosci 22: 3338-3341.

Rada P, Jensen K, Hoebel BG (2001). Effects of nicotine and mecamylamine-induced withdrawal on extracellular dopamine and acetylcholine in the rat nucleus accumbens. Psychopharmacology 157: 105-110.

Rahman S, Zhang J, Engleman EA, Corrigall WA (2004). Neuroadaptive changes in the mesoaccumbens dopamine system after chronic nicotine self-administration: a microdialysis study. Neuroscience 129: 415-424.

Rauhut AS, Hawrylak M, Mardekian SK (2008). Burpropion differentially alters the aversive, locomotor and rewarding properties of nicotine in CD-1 mice. Pharmacol Biochem Behav 90: 598-607.

Rice ME, Cragg SJ (2004). Nicotine amplifies reward-related dopamine signals in striatum. Nat Neurosci 7: 583-584.

Robinson TE, Berridge KC (2003). Addiction. Annu Rev Psychol 54: 25-53.

Rose JE, Corrigall WA (1997). Nicotine self-administration in animals and humans: similarities and differences. Psychopharmacology 130: 28-40.

Sellings LH, Baharnouri G, McQuade LE, Clarke PB (2008). Rewarding and aversive effects of nicotine are segregated within the nucleus accumbens. Eur J Neurosci 28: $342-352$.

Seppa T, Ruotsalainen M, Laakso I, Tuominen R, Ahtee L (2000). Effect of acute nicotine administration on striatal dopamine output and metabolism in rats kept at different ambient temperatures. Br J Pharmacol 130: 1147-1155.

Siu EC, Tyndale RF (2007). Characterization and comparison of nicotine and cotinine metabolism in vitro and in vivo in $\mathrm{DBA} / 2$ and C57BL/6 mice. Mol Pharmacol 71: 826-834.

Smolka MN, Buddhe H, Karow AC, Schmidt LG (2004). Neuroendocrinological and neuropsychological correlates of dopaminergic function in nicotine dependence. Psychopharmacol 175: 374-381.

Solomon RL, Corbit JD (1974). An opponent-process theory of motivation. I. Temporal dynamics of affect. Psychol Rev 81: 119-145.

Spina L, Fenu S, Longoni R, Rivas E, Di Chiara G (2006). Nicotine conditioned single-trial place preference: selective role of nucleus accumbens shell dopamine $\mathrm{D}_{1}$ receptors in acquisition. Psychopharmacology 184: 447-455.

Stoker AK, Semenova S, Markou A (2008). Affective and somatic aspects of spontaneous and precipitated nicotine withdrawal in $\mathrm{C} 57 \mathrm{BL} / 6 \mathrm{~J}$ and BALB/cByJ mice. Neuropharmacology 254: $1223-1232$

Stolerman IP, Jarvis MJ (1995). The scientific case that nicotine is addictive. Psychopharmacology 117: 2-10.

Stolerman IP, Shoaib M (1991). The neurobiology of tobacco addiction. Trends Pharmacol Sci 12: 467-473.

Tammimaki A, Chistyakov V, Patkina N, Skippari J, Ahtee L, Zvartau E et al (2008). Effect of forced chronic oral nicotine exposure on intravenous self-administration and rewarding properties of acute nicotine. Eur J Pharmacol 591: 164-170.

Tan H, Bishop SF, Lauzon NM, Sun N, Laviolette SR (2009). Chronic nicotine exposure switches the functional role of mesolimbic dopamine transmission in the procession of nicotine's rewarding and aversive effects. Neuropharmacol 56: 741-751.

Tanabe J, Crowley T, Hutchison K, Miller D, Johnson G, Du YP et al (2008). Ventral striatal blood flow is altered by acute 
nicotine but not withdrawal from nicotine. Neuropsychopharmacology 33: 627-633.

Ting-A-Kee R, Dockstader C, Heinmiller A, Grieder T, van der Kooy D (2009). GABA(A) receptors mediate the opposing roles of dopamine and the tegmental pedunculopontine nucleus in the motivational effects of ethanol. Eur J Neurosci 29: 1235-1244.

Vargas-Perez H, Ting-A-Kee R, van der Kooy D (2009). Difference neural systems mediate morphine reward and its spontaneous withdrawal aversion. Eur J Neurosci 29: 2029-2034.

Watkins SS, Stinus L, Koob GF, Markou A (2000). Reward and somatic changes during precipitated nicotine withdrawal in rats: centrally and peripherally mediated effects. J Pharmacol Exp Ther 292: 1053-1064.
Wilkinson JL, Bevins RA (2008). Intravenous nicotine conditions a place preference in rats using an unbiased design. Pharmacol Biochem Behav 88: 256-264.

Wise RA (1996). Neurobiology of addiction. Curr Opin Neurobiol 6: $243-251$.

Zhang H, Sulzer D (2004). Frequency-dependent modulation of dopamine release by nicotine. Nat Neurosci 7: 581-582.

Zhang T, Zhang L, Liang Y, Siapas A, Zhou F-M, Dani J (2009). Dopamine signaling differences in the nucleus accumbens and dorsal striatum exploited by nicotine. J Neurosci 29: 4035-4043.

Zito KA, Bechara A, Greenwood C, van der Kooy D (1988). The dopamine innervation of the visceral cortex mediates the aversive effects of opiates. Pharmacol Biochem Behav 30: 693-699. 